\title{
Endoparasites of Small Mammals in Edo State, Nigeria: Public Health Implications
}

\author{
Clement Isaac*, Benjamin Igho Igbinosa, John Asekhaen Ohiolei, Catherine Eki Osimen \\ Department of Zoology, Ambrose Alli University, Ekpoma, Nigeria
}

\begin{abstract}
Some small mammals occur as household pests and harbour a number of parasites that could be of public health importance. This study profiled the helminth and protozoan parasites in trapped small mammals within and around human dwelling places (houses) located across 4 major towns (Auchi, Benin, Ekpoma, and Uromi) and environs in Edo state, Nigeria. Six genera (Apodemus sp., Crocidura sp., Mastomys natalensis, Mus musculus, Rattus sp., and Sorex sp.) were identified from 502 trapped small mammals. Overall, M. musculus $(71.9 \%)$ and Rattus rattus $(20.1 \%)$ were the most frequently trapped. In total, on examination of blood, gastrointestinal contents, and brain tissues, 12 helminth taxa (Angiostrongylus sp., Aspicularis sp., Capillaria sp., Gongylonema sp., Heterakis spumosa, Hymenolepis diminuta, Hymenolepis nana, Mastophorus muris, Moniliformis moniliformis, Nippostrongylus brasiliensis, Strongyloides sp., Trichosomoides sp., and Trichuris sp.), and 6 protozoan parasites (Babesia sp., Trypanosoma lewisi, Plasmodium sp., Eimeria sp., Isospora sp., and Toxoplasma gondii) were isolated. Most prevalent helminths with relatively heavy mean intensity were Strongyloides sp. and Heterakis spumosa, while Plasmodium, Eimeria, and Isospora were the most prevalent protozoan parasites. Generally, intrinsic factors like sex and age had marginal influence on the rate and burden of infection in $M$. musculus and $R$. rattus. Although the infection rate and prevalence of zoonotic parasites were low, they were largely recovered in rodents from Ekpoma. This study elucidates the public health implication of the presence of zoonotic parasites in these small mammals.
\end{abstract}

Key words: Mus musculus, Rattus rattus, zoonotic parasite, Ekpoma

Common household pests in Nigeria are rodents and are ubiquitous. Rodents feed on a wide variety of food items and thus threaten food security and pose great risk to animal and human health [1]. Consequent upon the amount of damage potentially caused by rodents, people make efforts to rid their homes of these pests using different control methods. However, due to poor design and lack of maintenance of some houses in Nigeria [2] including periods when windows and doors without protective nets are left opened, small mammals continue to find ways in and out of human dwelling places. While rodents embark on outdoor activities, they are exposed to conditions in which soil and vector-borne parasites could be acquired [3]. Generally, parasites harboured by these mammals are largely a reflection of their presence and prevalence in the local environment. When parasite-positive rodents find their

\footnotetext{
- Received 21 September 2017, revised 26 January 2018, accepted 11 Feburuay 2018. *Corresponding authors (cle21200@gmail.com; clementisaac@aauekpoma.edu.ng) (c) 2018, Korean Society for Parasitology and Tropical Medicine This is an Open Access article distributed under the terms of the Creative Commons Attribution Non-Commercial License (http://creativecommons.org/licenses/by-nc/4.0) which permits unrestricted non-commercial use, distribution, and reproduction in any medium, provided the original work is properly cited.
}

way into homes, they defecate and urinate on household items; and if contaminated with zoonotic parasites, human residents and domestic animals (pets) are potentially at risk of infection [4].

In Nigeria, very few reliable studies have been carried out and have reported the helminth fauna, blood parasites, and ectoparasites of small mammals with observed variations in parasite profile and prevalence by location [3,5-8]. For instance, in Ibadan (South-West), Trichostrongylus columbriformis was reportedly the commonest nematode, while Hymenolepis diminuta was the only cestode recovered in Rattus rattus [9]. In Abeokuta (South-West), $64.7 \%$ of rodents were infected with one or more of the 7 species of recovered helminths [8]. Rodents trapped in the Niger Delta (South-South) had higher infection rates with nematodes than cestodes and trematodes [5]. Another study in Plateau (North-Central) demonstrates a high prevalence (83\%) of blood parasites in rodents [3]. The only study in Ekpoma, and effectively in Edo state, reported 17 helminth parasites in 8 species of small mammals [8]; and currently due to urbanization and climate change, it is believed that some changes in the small mammals' parasite's 
composition, distribution, and rate of infection may have occurred [10]. Additionally, for the first time, information regarding parasites of small mammals trapped in houses located in other major towns in Edo is presented. Intrinsic factors like age and sex of these mammals were also considered as possible determinants of the rate and burden of infection [10]. Furthermore, this study identifies Ekpoma as a potential hotspot for zoonotic parasites.

The vegetation cover in Nigeria is majorly rainforest in the south and savannah in the north. Among the states in Nigeria, Edo has these 2 vegetation types: savannah in the northern part and rainforest in the south. Small mammals in these 2 ecological zones were thus sampled in areas with these vegetation types being extrapolative for Nigeria particularly in locations with similar climatic, sanitary and housing conditions. Edo $\left(6^{\circ} 30^{\prime} \mathrm{N} 6^{\circ} 00^{\prime} \mathrm{E}\right)$ is an inland state in southern Nigeria. It has a tropical climate with 2 seasons: wet (April to October) and dry (November to March). The average rainfall is between $150 \mathrm{~mm}$ and $250 \mathrm{~mm}$. The 4 major towns of the state are $\mathrm{Au}-$ chi, Benin, Ekpoma, and Uromi.

Auchi $\left(5^{\circ} 54^{\prime} \mathrm{N} 5^{\circ} 40^{\prime} \mathrm{E}\right)$ located in the northern part of the state has a sub-humid tropical climate. The vegetation type is savannah and it is characterized by open grassland and few scattered fire-resistant trees. Topography is relatively undulating sloping from north to south with a sandy soil type. The human population size approximates to 142,819 with a landmass of $358 \mathrm{~km}^{2}$. Benin $\left(6^{\circ} 20^{\prime} \mathrm{N} 5^{\circ} 37^{\prime} \mathrm{E}\right)$ is the capital city of Edo with human population size of 1,147,188 and land mass of $1,204 \mathrm{~km}^{2}$. It has a humid climate located in a rainforest zone. Ekpoma $\left(6^{\circ} 45^{\prime} \mathrm{N} 6^{\circ} 08^{\prime} \mathrm{E}\right)$ houses the state university (Ambrose Alli University) and has a population size of above 80,000 with landmass of $62 \mathrm{~km}^{2}$. Uromi $\left(6^{\circ} 71^{\prime} \mathrm{N} 6^{\circ} 32^{\prime} \mathrm{E}\right)$ has a landmass of $60 \mathrm{~km}^{2}$ with population size of less than 65,000 .

Before collection of the animals, approval (AAUBREC: 16/ 008) to trap and sacrifice was obtained from the Ambrose Alli Bioethics Research Committee. Trapping was done for a period of 6 months between April and September 2016. These small mammals were collected using sticky traps baited with pieces of food items, e.g. smoked fish, and positioned within and around human residences. The total number of housing units where small mammals were sampled were 331 across the surveyed areas, Auchi $(\mathrm{n}=38)$, Benin $(\mathrm{n}=110)$, Ekpoma $(\mathrm{n}=112)$, and Uromi $(\mathrm{n}=71)$, at night, and the trap was left till the morning of the next day. Most houses in Nigeria have perimeter fences and both are built with cement and mortar; so we ensured that traps placed outdoor were restricted to the fenced areas. Two to 3 sticky traps were positioned indoors and outdoors in each residential building for 2 to 3 days and checked at intervals (between 5 and $6 \mathrm{hr}$ ). When catches were made, these mammals were immediately transported to the laboratory for processing.

These small mammals were carefully removed from the sticky traps alive and further immobilized using chloroform. Already dead small mammals on traps were not processed and examined for parasites. Information regarding location (indoor or outdoor) of catches including home and street addresses was noted. Samples were correctly identified. Also, the sex of the small mammals were recorded while the age classes (adults, sub-adults, and juveniles) were equally determined and documented using the indices of the tail length, body length, and body weight $[11,12]$. After dissection, blood from the heart was collected using needle syringes. Also, capillary tubes were used to collect blood from the retro-orbital plexus. For parasite detection and identification, thick and thin blood smears were respectively made on slides and then stained with Giemsa solution and allowed to dry. Babesia (sometimes stained in circular or tetrad forms) and Plasmodium (sometimes seen as thick dots or shaped in a ring form) in the red blood cells were identified $[13,14]$. Meanwhile, blood collected in the heparinized capillary tubes was centrifuged, and the buffy coat layer was separated and examined for the detection as well as identification of trypanosomes [15].

For gastrointestinal parasite investigation, the stomach was dissected and contents emptied; while the feces in the intestines were removed into standing tubes containing sucrose solution on which ova had to float. Cover slips were placed on the standing tubes, and floating helminth ova were allowed to stick to the surface. Parasites were identified using their distinct morphological features [16]. The mean intensity (MI) of ova were estimated and recorded. In addition, the small mammals were decapitated, and the skin removed to expose the skull so as to access portions of the brain by cutting through it. About 1-2 mm sized portion of the cerebrum was separated and squashed between 2 slides and examined for the presence of any brain parasites. Cysts isolated were compared with the features of already described T. gondii cysts from a mouse brain [17]; and features were similar as there was a thin cyst wall containing clusters of bradyzoite cells that are largely shaped in comma form. Carcasses were properly disposed according to Ambrose Alli University animal research ethics guidelines. 


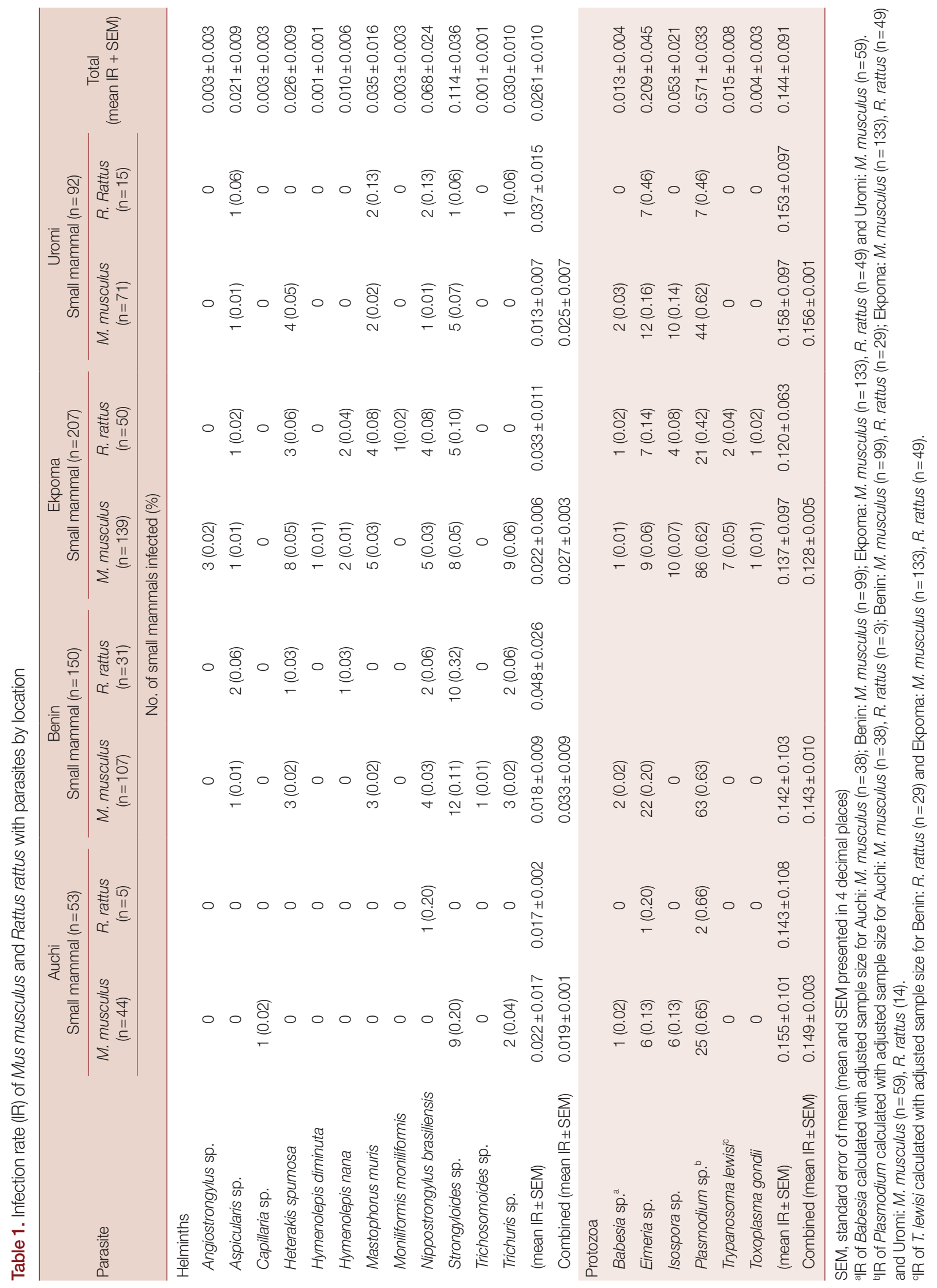


Gastrointestinal and brain parasites (helminths) were identified under the microscope (AXL [3180976] Labo Germany) using $\times 40$ magnification, while blood parasites were viewed using $\times 100$ magnification.

The Simpson's index of diversity (SID) formula [18] was applied to the data. Parasite prevalence (number of species of small mammal positive for respective parasite by location/total number of species of small mammal examined for parasitic infection by location $\times 100$ ) in trapped small mammals were estimated (see additional file). Also, infection rates (number of Mus musculus or/and R. rattus positive for helminth or protozoan parasites by location/total number of M. musculus or/ and $R$. rattus examined for helminth or protozoan parasites by location) for M. musculus and $R$. rattus with respective parasites are presented in Table 1. Mean differences relating to infection rates and intensity by sex and age for helminth and protozoan parasites were evaluated using student $t$-test and 1-way ANOVA with GraphPad Prism 5 version 5.01. Results were considered significant at $P<0.05$.

A total of 502 small mammals were trapped. Overall, catches around house premises included; 3 (0.59\%) Apodemus sp., $1(0.19 \%)$ Crocidura sp., 7 (1.3\%) Mastomys natalensis, 361
(71.9\%) M. musculus, 22 (4.4\%) Rattus norvegicus, 101 (20.1\%) $R$. rattus, and 7 (1.4\%) Sorex sp. (see additional file). M. musculus, $R$. rattus, R. norvegicus, and M. natalensis were seen in all locations, while Sorex sp. were trapped in Benin, Ekpoma, and Uromi (see additional file). Apodemus sp. were caught in Benin and Uromi, while Crocidura sp. was trapped in Ekpoma only (see additional file). Species diversity was generally low across locations with Ekpoma higher than others (see additional file). In all, more males were sampled than females and more adults than other age classes.

Cumulatively, there were 12 helminth taxa, namely, Angiostrongylus sp. (larvae), Aspicularis sp. (ova), Capillaria sp. (ova), Gongylonema sp. (ova), Heterakis spumosa (ova), H. diminuta (ova), H. nana (ova), Mastophorus muris (ova), Moniliformis moniliformis (larvae), Nippostrongylus brasiliensis (ova), Strongyloides sp. (ova), Trichosomoides sp. (ova), and Trichuris sp. (ova), identified with at least a helminth taxon recovered in one or more small mammals. The most occurring helminth parasites were N. brasiliensis and Strongyloides sp. with relatively high infection rates (Table 1). Very low mean infection rates were recorded for Capillaria sp. (Auchi), Angiostrongylus sp., H. diminuta, and Trichosomoides sp. in M. musculus from Ekpoma (Table 1). $R$.

Table 2. Prevalence and mean intensity (MI) per gram of feces, brain tissue, or blood of parasites in Mus musculus and Rattus ratttus

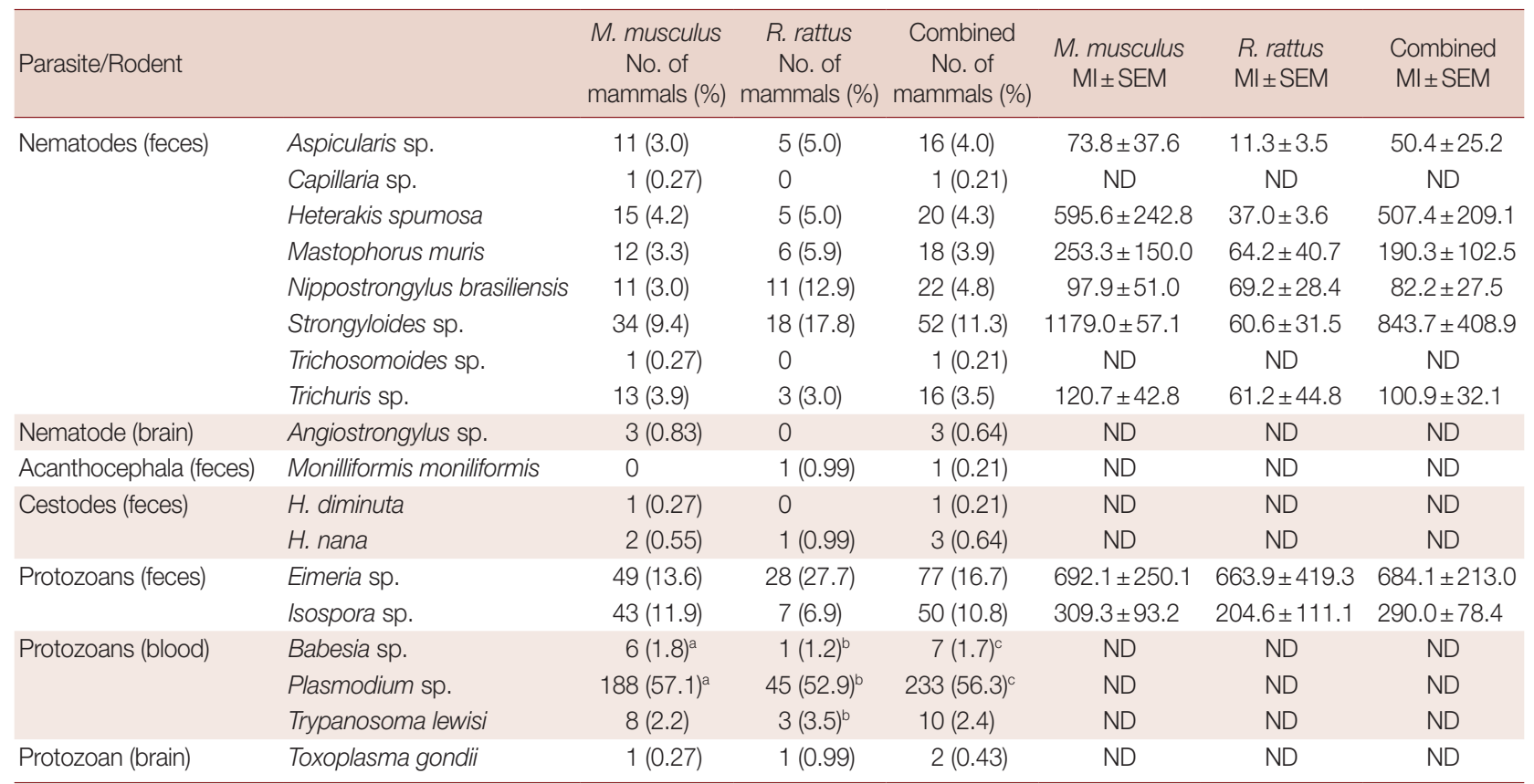

SEM, standard error of mean; ND, not determined.

a\% positive calculated with the sample size of $M$. musculus $(n=329)$.

b\% positive calculated with the sample size of $R$. rattus $(n=85)$.

c\% positive calculated with the combined sample size of $M$. musculus and $R$. rattus $(\mathrm{n}=414)$. 
rattus $(\mathrm{n}=1)$ from Ekpoma was positive for M. moniliformis, while ova of Gongylonema sp. were recovered in R. norvegicus sampled in Benin and Ekpoma (see additional file). In all, the infection rate for $R$. rattus $(0.036 \pm 0.009)$ was higher than $M$. musculus $(0.023 \pm 0.006)$ but mean difference was not significant $(t=1.17 ; P>0.05)$. Also, Auchi recorded the lowest mean infection rate in relation to other locations but with marginal mean difference $(\mathrm{F}=0.35 ; P>0.05)$ (Table 1$)$. In addition, Strongyloides sp. and $H$. spumosa were the most prevalent with relatively high mean intensity (MI) (Table 2).

The prevalence of M. musculus and $R$. rattus with 2 or more helminth taxa against the total number of helminth-positive small mammals per location was: 4 (26.7\%) and 1 (33.3\%) in Auchi, 18 (46.2\%) and 8 (53.3\%) in Benin, 13 (31.0\%) and 11 (68.8\%) in Ekpoma and 10 (55.6\%) and 5 (71.4\%) in Uro$\mathrm{mi}$, respectively. The number of $R$. norvegicus in which 2 or more helminth parasites were isolated was: Benin $(\mathrm{n}=3)$, Ekpoma $(\mathrm{n}=8)$, and Uromi $(\mathrm{n}=7)$. In Ekpoma, M. natalensis $(\mathrm{n}=1)$ and Sorex sp. $(\mathrm{n}=1)$ were positive of 2 helminth taxa with similar result for Apodemus sp. $(\mathrm{n}=1)$ (Uromi $=$ data not presented).

The protozoan parasites detected were; blood parasites (Babesia sp., Trypanosoma lewisi, and Plasmodium sp.), intestinal parasites (oocysts of Eimeria sp. and Isospora sp.), and brain parasites (cysts of Toxoplasma gondii). Of significance was the presence of Plasmodium sp. in more than a half of the number of rodents examined and the detection of Babesia sp. in all surveyed sites (Tables 1, 2). T. lewisi was seen only in Ekpoma (university hostel) and Benin (Sapele road) foci (Table 1). Differences in the rates of helminth infections for M. musculus $(0.149 \pm 0.040)$ and $R$. rattus $(0.142 \pm 0.040)$ including across locations were not significant $(P>0.05)$ (Table 1$)$.

Data analysis indicated null effect of sex on helminth infection rate in M. musculus (male $=0.023 \pm 0.007$; female $=0.015 \pm$ $0.010 ; t=0.67, P=0.50$ ), but marked difference for $R$. rattus (male $=0.204 \pm 0.008 ;$ female $=0.061 \pm 0.019 ; t=2.45, P=0.04$ ). Generally, adults had higher infection rates than sub-adults and juveniles, but mean differences were not significant for $M$. musculus (adults $=0.025 \pm 0.012$; sub-adults $=0.016 \pm 0.005$; juveniles $=0.0127 \pm 0.004 ; \mathrm{F}=0.54, P=0.58$ ) and $R$. rattus (adults $=0.047 \pm 0.016$; sub-adults $=0.035 \pm 0.017$; juveniles $=0.018 \pm$ $0.011 ; \mathrm{F}=1.02, P=0.37)$.

The parasite load for 6 helminths (Aspicularis sp., H. spumosa, M. muris, Trichuris sp., Strongyloides sp., and N. brasiliensis) having $\geq 7$ positive samples in M. musculus and $R$. rattus was pooled to estimate the parasite MI. The differences in the
MI relating to sex for M. musculus (male $=427.3 \pm 195.7$; female $=244.3 \pm 136.5 ; t=0.76 ; P=0.45$ ) and $R$. rattus (male $=$ $91.6 \pm 36.6$; female $=70.8 \pm 42.1$ ) were not significant $(t=0.37$, $P=0.71)$. With regards to parasite load and age of $M$. musculus, adults had higher MI $(544.4 \pm 212.4)$ than sub-adults (238.9 $\pm 88.5)$ and juveniles $(65.8 \pm 35.6)(\mathrm{F}=9.27 ; P=0.009)$. For $R$. rattus, sub-adults $(95.8 \pm 449.2)$ had higher MI than adults $(42.2 \pm 23.2)$ and juveniles $(9.2 \pm 9.2)(\mathrm{F}=8.088 ; P=0.017)$. Overall, the MI for M. musculus (386.5 \pm 177.2$)$ was higher than $R$. rattus $(50.5 \pm 9.1)(t=2.62, P=0.043)$.

Considering mean infection rate with protozoan parasites, sexes were of null effect for M. musculus (male $=0.023 \pm 0.006$; female $=0.036 \pm 0.009 ; t=0.75, P=0.314$ ) and $R$. rattus (male $=$ $0.172 \pm 0.041$; female $=0.087 \pm 0.041 ; t=0.82, P=0.426)$. Similarly, there was no significant difference across age classes for M. musculus (adults $=0.164 \pm 0.092$; sub-adults $=0.1873 \pm 0.126$; juveniles $=0.183 \pm 0.147 ; \mathrm{F}=0.0093, P=0.99$ ); while for $R$. rattus, sub-adults had higher infection rate than other age classes (adults $=0.072 \pm 0.051$; sub-adults $=0.154 \pm 0.067$; juveniles $=$ $0.082 \pm 0.052)$ with marginal mean difference $(\mathrm{F}=0.62, P=0.54)$.

Small mammals especially rodents are seen in most homes in Nigeria and are known to facilitate the deterioration of household items. So, the importance of delineating the spectrum of rodents in a given location as well as determining its rate of occurrence cannot be overstated as they would guide on the appropriate trapping methods for optimum results. Data presented here have generally shown that small mammals in sampled locations around and within residential buildings are primarily M. musculus followed by $R$. rattus and $R$. norvegicus.

Overall, across study locations, a total of 12 helminth taxa were recovered in the sampled small mammals. In Auchi, helminth diversity was relatively low. The results of parasites diversity in Auchi in comparison to Benin, Ekpoma, and Uromi could attest to the variation in ecological conditions and better sanitary conditions in Auchi (personal observations). In contrast, for Ekpoma, we observed that waste disposal is relatively a big challenge as the town is littered with piles of household waste. More so, due to increasing population size, sanitary conditions have worsened with dilapidated roads and poor drainage systems. However, it is important to add that previous report from Ekpoma indicated greater number of helminth parasites in small mammals; and this is largely attributable to survey efforts covering wider sampling areas [7].

Aside from external conditions, some intrinsic factors like 
sex and age of small mammals have been advanced to influence the occurrence of infection with helminths $[7,19]$. We only analyzed data for M. musculus and $R$. rattus because of a relatively large sample size. Results for M. musculus showed null effect of sex and age on infection rate but higher helminth-parasite load for adults than other age groups. However, for $R$. rattus, the rate of helminth infections in male was higher than female; and also, sub-adults had greater MI than other age classes. This suggests that the sub-adults are more active in foraging for food materials and thus more exposed to helminth infections whilst still immunologically naive [7]. Furthermore, males are considered to have weaker immune responses than females and hence less resistant to helminth parasites [20].

The helminth community profiled in M. musculus and $R$. rattus broadly places Strongyloides sp. and H. spumosa as the most occurring with the highest helminth-parasite burden. Strongyloides sp. have unusual life cycle and the relatively high prevalence may be partly due to suitable ecological conditions for the development of larvae into infective larvae stage [21].

In Ekpoma, 4 potentially zoonotic helminth parasites ( $\mathrm{An}$ giostrongylus sp., H. diminuta, M. moniliformis, and Gongylonema sp.) were isolated. The larvae of Angiostrongylus sp. were recovered in the brain tissue of M. musculus. Generally, snails are the primary intermediate hosts but in particular, only Achatina fulica, an edible land snail has been identified in Edo to harbour Angiostrongylus sp. [22]. Humans may become infected through ingestion of larvae and could develop eosinophilic meningitis [23]. M. musculus, R. norvegicus and Sorex sp. were positive for $H$. diminuta. The presence of positive rodents with $H$. diminuta is a major risk factor to human health [24]. M. moniliformis was another intestinal parasite seen in a rodent ( $R$. rattus); and its presence could potentially be of public health importance [25]. In addition, Gongylonema sp. was isolated in $R$. norvegicus from Ekpoma and Benin. Human infection with Gongylonema sp. occurs mostly through intake of contaminated water with symptom of discomfort in the mouth, lips, and in the soft palate area [26]. Capillaria sp. ova were recovered in the intestine of M. musculus in Auchi. Capillaria hepatica is known to potentially cause human infections [27].

Oocysts of Eimeria and Isospora in the intestinal feces were differentiated by the presence or absence of micropyle cap on its respective surfaces. The prevalence and MI of Eimeria and Isospora in rodents in all study locations indicates their heavy presence in the environment. This clearly suggests that the ani- mals in these locations may be heavily burdened with Isospora and Eimeria parasites. Infection with Isospora could lead to transient diarrhoea, colic, weight loss and fever in dogs, cats, pigs, and man; while for Eimeria, diarrhoea is the major clinical manifestation in goats, sheep, cattle, and birds. Also, the cyst of $T$. gondii was seen only in the brain sample of rodents (M. musculus [ $\mathrm{n}=1]$ and $R$. rattus $[\mathrm{n}=1]$ ) caught in Ekpoma, suggesting that this area could be potentially endemic for the parasite. Pregnant women and immune-compromised persons like HIV positive persons are most susceptible because they could suffer complications arising from T. gondii infection [28].

The findings of Babesia and Plasmodim in rodents in the 4 study locations suggested active transmission of these parasites by ticks and mosquitoes, respectively. The prevalence of Babesia among humans is not known in these areas. Since there is regular man-dog contact, there is the possibility of human infection with Babesia albeit very low. Because diagnosis of blood samples for Babesia is not a routine procedure, transfusion of infected blood to others is likely. More than half of the trapped rodents were positive of Plasmodium and to a certain degree could be a reflection of the incidence level of human malaria. The pathology of infection with Plasmodium berghei can be comparable to infection with P. falciparum [29].

Our result shows that of the 12 rodents (M. musculus and $R$. rattus) caught in a particular location in Ekpoma (university hostel), nine were positive of T. lewisi. Similarly, in Benin (Sapele road), a positive sample was recorded. To our knowledge this is the first report of the presence of trypanosomes in Edo state. In November 2015 in Sapele, a human case of trypanosome-positive blood was detected in this area (personal communication). Therefore, atypical human trypanosomiasis is/are likely in these foci [15] and thus should be further investigated.

Clearly, we have identified Ekpoma as a potential hotspot for the presence of zoonotic parasites. By extension, environmental sanitary conditions with similar ecological factors could berth similar results in a number of places in Nigeria and possibly in some developing tropical countries across the globe. So, Ekpoma may just be a case in point to further advocate for improved personal hygiene and strengthen environmental sanitation system. However, the number of helminth parasites isolated across locations may not be exhaustive as only limited tissues/organs were examined. Likewise, in future, the application of molecular tools to further discriminate some of these parasites may be highly useful. From the results 
on trypanosome-positive rodents, we urge the Pan African Tsetse and Trypanosomiasis Eradication Campaign (PATTEC) and relevant bodies to screen human population in places where trypanosomes were isolated; and also carry out comprehensive tsetse surveillance across Edo state to properly delineate tsetse belt. As much as possible, houses should be constructed in a way they are small-mammal proof; and that continued efforts to rid homes of small mammals be highly encouraged.

\section{ACKNOWLEDGMENTS}

We appreciate the efforts of our 400 Level students (2015/ 2016 session) in the Department of Zoology, Ambrose Alli University, Ekpoma, Nigeria as they were largely involved in the trapping of these animals as well as sample processing.

\section{CONFLICT OF INTEREST}

We declare that we have no conflict of interest related to this work.

\section{REFERENCES}

1. Meerburg BG, Singleton GR, Leirs H. The year of the rat ends: time to fight hunger. Pest Manag Sci 2009; 65: 351-352.

2. Omudu EA, Ati TT. A survey of rats trapped in residential apartments and their ectoparasites in Makurdi Nigeria. Res J Agric Biol Sci 2010; 6: 144-149.

3. Ajayi OO, Ogwurike BA, Ajayi JA. Blood protozoan parasites of rodents in Jos Plateau State Nigeria. Anim Prod Res Adv 2006; 2 : 202-207.

4. Youssef AI, Uga S. Review of parasitic zoonoses in Egypt. Trop Med Health 2014; 42: 3-14.

5. Udonsi JK. Helminth parasites of wild populations of the black rat, Rattus rattus (L.) from urban, residential and other ecological areas of Nigeria. Acta Parasitol Polonica 1989; 34: 107-116.

6. Ugbomoiko US, Obiamiwe BA. Helminths of small mammals in a forest zone of Southern Nigeria. Helminthologia 1991; 28: 19-22.

7. Mafiana CF, Osho MB, Sam-Wobo S. Gastrointestinal helminth parasites of black rat (Rattus rattus) in Abeokuta, Southwest Nigeria. J Helminthol 1997; 71: 217-220.

8. Akinboade OA, Dipeolu OO, Ogunji FO, Adegoke GO. The parasites obtained and bacteria isolated from house rats (Rattus rattus Linnaeus, 1758) caught in human habitations in Ibadan, Nigeria. Int J Zoonoses 1981; 8: 26-32.

9. Buzane E, Zupan, S, Jugovic, J. Changes in rodent communities as consequence of urbanization and inappropriate waste management. AEER 2016; 15: 573-588.
10. Mohd Zain SN, Behnke JM, Lewis JW. Helminth communities from two urban rat populations in Kuala Lumpur Malaysia. Parasit Vectors 2012; 7: 47.

11. Katarannovski D, Katarannovski M, Savc IR, Soldatociv B, Matic R. Morphometric and biochemical parameters as age indicators in the Norway rats (Rattus norvegicus Berk, 1769). Acta Vet 1994; 4: 371-378.

12. Cunningham DM, Moors PJ. Guide to the Collection and Identification of New Zealand Rodents. 3rd ed. Wellington, New Zealand. Department of Conservation. 1996, pp 10-21.

13. Herwaldt BL, Cacciò $S$, Gherlinzoni F, Aspöck H, Slemenda SB, Piccaluga P, Martinelli G, Edelhofer R, Hollenstein U, Poletti G, Pampiglione S, Löschenberger K, Tura S, Pieniazek NJ. Molecular characterization of a non-Babesia divergens organism causing zoonotic babesiosis in Europe. Emerg Infect Dis 2003; 9: 943948.

14. Lee KS, Cox-Singh J, Singh B. Morphological features and differential counts of Plasmodium knowlesi parasites in naturally acquired human infections. Malar J 2009; 8: 73.

15. Truc $P$, Büscher $P$, Cuny G, Gonzatti MI, Jannin J, Joshi $P$, Juyal $P$, Lun ZR, Mattioli R, Pays E, Simarro PP, Teixeira MM, Touratier L, Vincendeau P, Desquesnes M. Atypical human infections by animal trypanosomes. PLoS Neg Trop Dis 2013; 7: e2256.

16. Foreyt WJ. Veterinary Parasitology Reference Manual. 5th ed. Ames, Iowa. Blackwell Publishing Professional. 2001, pp 45222.

17. Bowman DD. Georgis' Parasitology for Veterinarians. 9th ed. Missouri, USA. Elsevier. 2009, p 805-1112.

18. Simpson EH. Measurement of diversity. Nature 1949; 163: 688688.

19. Poulin R. Sexual inequalities in helminth infections: a cost of being a male? Am Nat 1996; 147: 287-295.

20. Luong LT, Grear DA, Hudson PJ. Male hosts are responsible for the transmission of a trophically transmitted parasite Pterygodermatites peromysci to the intermediate host in the absence of sexbiased infection. Int J Parasitol 2009; 39: 1263-1268.

21. Harvey SC, Gemill, AW, Read AF, Viney ME. The control of morph development in the parasitic nematode Strongyloides ratti. Proc Biol Sci 2000; 267: 2057-2063.

22. Igbinosa IB, Isaac $\mathrm{C}$, Adamu HO, Adeleke G. Parasites of edible land snails in Edo State Nigeria. Helminthologia 2016; 53: 331335.

23. Lv S, Zhang Y, Chen SR, Wang LB, Fang W, Chen F, Jiang JY, Li YL, Du ZW, Zhou XN. Human angiostrongyliasis outbreak in Dali, China. PLoS Neg Trop Dis 2009; 3: e520.

24. Marangi M, Zechini B, Fileti A, Quaranta G, Aceti A. Hymenolepis diminuta infection in a child living in the urban area of Rome Italy. J Clin Microbiol 2003; 41: 3994-3995.

25. Berenji F, Fata A, Hosseininejad Z. A case of Moniliformis moniliformis (Acanthocephala) infection in Iran. Korean J Parasitol 2007; 45: 145-148.

26. Haruki K, Furuya H, Saito S, Kamiya S, Kagei N. Gongylonema infection in man: a first case of gongylonemosis in Japan. Helmin- 
thologia 2005; 42: 63-66.

27. Ferreira LA, Andrade ZA. Capillaria hepatica: a cause of septal fibrosis of the liver. Mem Inst Oswaldo Cruz 1993; 88: 441-447.

28. Deji-Agboola AM, Busari OS, Osinupebi OA, Amoo AOJ. Seroprevalence of Toxoplasma gondii antibodies among pregnant women attending antenatal clinic of Federal Medical Center Lagos
Nigeria. Int J Bio Med Res 2011; 2: 1135-1139.

29. Franke-Fayard B, Fonager J, Braks A, Khan SM, Janse CJ. Sequestration and tissue accumulation of human malaria parasites: can we learn anything from rodent models of malaria? PLoS Pathog 2010; 6: e1001032. 
Supplementary Table 1. Distribution of small mammal in the study areas

\begin{tabular}{|c|c|c|c|c|c|c|c|c|c|c|}
\hline Location & Small mammals & $\begin{array}{l}\text { No. } \\
\text { trapped }\end{array}$ & $\begin{array}{l}\text { No. trapped } \\
\text { indoor }\end{array}$ & $\begin{array}{l}\text { No. trapped } \\
\text { outdoor }\end{array}$ & M & $\mathrm{F}$ & $A$ & SA & $J$ & SID \\
\hline \multirow[t]{5}{*}{ Auchi } & M. natalensis & 2 & 1 & 1 & 1 & 1 & 1 & 1 & 0 & 0.3 \\
\hline & M. musculus & 44 & 29 & 15 & 40 & 4 & 22 & 14 & 8 & \\
\hline & R. rattus & 5 & 4 & 1 & 4 & 1 & 2 & 2 & 1 & \\
\hline & R. norvegicus & 2 & 0 & 2 & 2 & 0 & 2 & 0 & 0 & \\
\hline & Subtotal & 53 & 34 & 19 & 47 & 6 & 27 & 17 & 9 & \\
\hline \multirow[t]{7}{*}{ Benin } & Apodemus sp. & 2 & 2 & 0 & 2 & 0 & 2 & 0 & 0 & 0.44 \\
\hline & M. natalensis & 1 & 1 & 0 & 0 & 1 & 0 & 1 & 0 & \\
\hline & M. musculus & 107 & 85 & 22 & 82 & 25 & 56 & 31 & 20 & \\
\hline & R. rattus & 31 & 17 & 13 & 23 & 8 & 10 & 21 & 0 & \\
\hline & R. norvegicus & 5 & 2 & 3 & 2 & 3 & 1 & 4 & 0 & \\
\hline & Sorex sp. & 4 & 4 & 0 & 3 & 1 & 2 & 2 & 0 & \\
\hline & Subtotal & 150 & 112 & 38 & 112 & 38 & 71 & 59 & 20 & \\
\hline \multirow[t]{7}{*}{ Ekpoma } & Crocidura sp. & 1 & 0 & 1 & 0 & 1 & 1 & 0 & 0 & 0.48 \\
\hline & M. natalensis & 2 & 2 & 0 & 1 & 1 & 1 & 1 & 0 & \\
\hline & M. musculus & 139 & 132 & 7 & 107 & 32 & 66 & 51 & 22 & \\
\hline & R. rattus & 50 & 45 & 5 & 45 & 5 & 16 & 23 & 11 & \\
\hline & R. norvegicus & 13 & 10 & 3 & 11 & 2 & 6 & 7 & 0 & \\
\hline & Sorex sp. & 2 & 2 & 0 & 0 & 2 & 2 & 0 & 0 & \\
\hline & Subtotal & 207 & 191 & 16 & 165 & 42 & 92 & 82 & 33 & \\
\hline \multirow[t]{7}{*}{ Uromi } & Apodemus sp. & 1 & 0 & 1 & 1 & 0 & 1 & 0 & 0 & 0.38 \\
\hline & M. natalensis & 2 & 2 & 0 & 0 & 2 & 1 & 1 & 0 & \\
\hline & M. musculus & 71 & 63 & 8 & 57 & 14 & 51 & 12 & 8 & \\
\hline & R. rattus & 15 & 11 & 4 & 12 & 3 & 0 & 12 & 3 & \\
\hline & R. norvegicus & 2 & 0 & 2 & 1 & 1 & 1 & 1 & 0 & \\
\hline & Sorex sp. & 1 & 1 & 0 & 0 & 1 & 1 & 0 & 0 & \\
\hline & Subtotal & 92 & 77 & 15 & 70 & 22 & 55 & 26 & 11 & \\
\hline Grand total & & 502 & 414 & 88 & 394 & 108 & 245 & 184 & 73 & 0.45 \\
\hline
\end{tabular}

M, Male; F, Female; A, Adult; SA, Sub-adult; J, Juvenile; SID, Simpson's index of diversity. 
Supplementary Table 2. Prevalence of parasites of rodents trapped in Auchi

\begin{tabular}{|c|c|c|c|c|c|c|}
\hline \multirow{2}{*}{\multicolumn{2}{|c|}{ Parasite/small mammal }} & \multicolumn{5}{|c|}{ No. of mammals (\%) } \\
\hline & & \multirow{2}{*}{$\begin{array}{l}\begin{array}{c}\text { M. natalensis } \\
(n=2)\end{array} \\
0\end{array}$} & \multirow{2}{*}{$\begin{array}{l}\text { M. musculus } \\
(n=44)\end{array}$} & \multirow{2}{*}{$\begin{array}{c}\text { R. rattus } \\
(n=5)\end{array}$} & \multirow{2}{*}{$\begin{array}{l}\text { R. norvegicus } \\
(n=2)\end{array}$} & \multirow{2}{*}{$\begin{array}{c}\begin{array}{c}\text { Total } \\
(n=53)\end{array} \\
1(1.9)\end{array}$} \\
\hline Intestinal parasites & Capillaria sp. & & & & & \\
\hline & Eimeria sp. & $2(100.0)$ & $6(13.6)$ & $1(20.0)$ & 0 & $9(17.0)$ \\
\hline & Isospora sp. & 0 & $6(13.6)$ & 0 & 0 & $6(11.3)$ \\
\hline & Nippostrongylus brasiliensis & 0 & 0 & $1(25.0)$ & 0 & $1(1.9)$ \\
\hline & Strogyloides sp. & 0 & $9(20.5)$ & 0 & 0 & $9(17.0)$ \\
\hline & Trichuris sp. & 0 & $2(4.5)$ & 0 & 0 & $2(3.8)$ \\
\hline \multirow[t]{2}{*}{ Blood parasites } & Babesia sp. & 0 & $1(2.6)^{a}$ & 0 & 0 & $1(2.2)^{c}$ \\
\hline & Plasmodium sp. & $1(50.0)$ & $25(65.8)^{\mathrm{a}}$ & $2(66.7)^{b}$ & $2(100.0)$ & $30(66.7)^{c}$ \\
\hline Brain parasites & - & - & - & - & - & - \\
\hline
\end{tabular}

aPercentage positive calculated with M. musculus sample size $(n=38)$.

${ }^{b}$ Percentage positive calculated with $R$. rattus sample size $(n=3)$.

'Percentage positive calculated with a total rodent sample size $(n=45)$. 
Supplementary Table 3. Prevalence of parasites of small mammals trapped in Benin

\begin{tabular}{|c|c|c|c|c|c|c|c|c|}
\hline \multirow{2}{*}{\multicolumn{2}{|c|}{ Parasite/small mammal }} & \multicolumn{7}{|c|}{ No. of mammals (\%) } \\
\hline & & \multirow{2}{*}{$\begin{array}{l}\text { Apodemus sp. } \\
(n=2)\end{array}$} & \multirow{2}{*}{$\begin{array}{l}\text { M. natalensis } \\
(n=1)\end{array}$} & \multirow{2}{*}{$\begin{array}{c}\text { M. musculus } \\
(n=107) \\
1(0.93)\end{array}$} & \multirow{2}{*}{$\begin{array}{l}\begin{array}{c}\text { R. rattus } \\
(n=31)\end{array} \\
2(6.5)\end{array}$} & \multirow{2}{*}{$\begin{array}{l}\text { R. norvegicus } \\
(n=5)\end{array}$} & \multirow{2}{*}{$\begin{array}{l}\text { Sorex sp. } \\
(n=4)\end{array}$} & \multirow{2}{*}{$\begin{array}{c}\begin{array}{c}\text { Total } \\
(n=150)\end{array} \\
3(2)\end{array}$} \\
\hline Intestinal parasites & Aspicularis sp. & & & & & & & \\
\hline & Eimeria sp. & 0 & 0 & $22(20.6)$ & $10(32.3)$ & $2(40.0)$ & 0 & $34(22.7)$ \\
\hline & Gongylonema sp. & 0 & 0 & 0 & 0 & $1(20.0)$ & 0 & $1(0.66)$ \\
\hline & Heterakis spumosa & 0 & 0 & $3(2.8)$ & $1(3.2)$ & 0 & 0 & $4(2.7)$ \\
\hline & Hymenolepis nana & 0 & 0 & 0 & $1(3.2)$ & 0 & 0 & $1(0.66)$ \\
\hline & Isospora sp. & 0 & 0 & $17(15.9)$ & $2(6.5)$ & 0 & 0 & $19(12.7)$ \\
\hline & Mastophorus muris & 0 & 0 & $3(2.8)$ & 0 & 0 & 0 & $3(2.0)$ \\
\hline & Nippostrongylus brasiliensis & 0 & 0 & $4(3.7)$ & $2(6.5)$ & $1(20.0)$ & 0 & $7(4.7)$ \\
\hline & Strongyloides sp. & $2(100.0)$ & 0 & $12(11.2)$ & $10(32.3)$ & $2(40.0)$ & 0 & $26(17.3)$ \\
\hline & Trichosomoides sp. & 0 & 0 & $1(0.93)$ & 0 & 0 & 0 & $1(0.66)$ \\
\hline & Trichuris sp. & 0 & 0 & $3(2.8)$ & $2(6.5)$ & $1(20.0)$ & 0 & $6(4.0)$ \\
\hline \multirow[t]{3}{*}{ Blood parasites } & Babesia sp. & 0 & 0 & $2(2.0)^{a}$ & 0 & 0 & 0 & $2(1.5)^{c}$ \\
\hline & Plasmodium sp. & $1(50.0)$ & $1(100.0)$ & $63(63.6)^{\mathrm{a}}$ & $15(51.7)^{b}$ & $3(60.0)$ & $3(75.0)$ & $87(64.4)^{c}$ \\
\hline & Trypanosoma lewisi & 0 & 0 & 0 & $1(3.4)^{b}$ & 0 & 0 & $1(0.74)^{c}$ \\
\hline Brain parasites & - & - & - & - & - & - & - & - \\
\hline
\end{tabular}

aPercentage positive calculated with M. musculus sample size $(n=99)$.

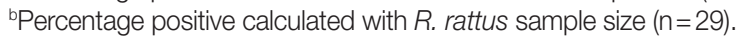

${ }^{c}$ Percentage positive calculated with a total rodent sample size $(n=135)$. 
Supplementary Table 4. Prevalence of parasites of small mammals trapped in Ekpoma

\begin{tabular}{|c|c|c|c|c|c|c|c|c|}
\hline \multirow{2}{*}{\multicolumn{2}{|c|}{ Parasite/small mammal }} & \multicolumn{7}{|c|}{ No. of mammals (\%) } \\
\hline & & \multirow{2}{*}{$\begin{array}{l}\text { Crocidura sp. } \\
\quad(n=1)\end{array}$} & \multirow{2}{*}{$\begin{array}{c}\text { M. natalensis } \\
(n=2)\end{array}$} & \multirow{2}{*}{$\begin{array}{c}\text { M. musculus } \\
(n=139) \\
1(0.71)\end{array}$} & \multirow{2}{*}{$\begin{array}{c}\text { R. rattus } \\
(n=50)\end{array}$} & \multirow{2}{*}{$\begin{array}{l}\text { R. norvegicus } \\
(n=13)\end{array}$} & \multirow{2}{*}{$\begin{array}{c}\text { Sorex sp. } \\
(n=2)\end{array}$} & \multirow{2}{*}{$\begin{array}{c}\text { Total } \\
(n=207)\end{array}$} \\
\hline Intestinal parasites & Aspicularis sp. & & & & & & & \\
\hline & Eimeria sp. & 0 & 0 & $9(6.5)$ & $7(14.0)$ & $1(7.7)$ & 0 & 17 (8.2) \\
\hline & Gongylonema sp. & 0 & 0 & 0 & 0 & $1(7.7)$ & 0 & $1(0.48)$ \\
\hline & H. spumosa & 0 & 0 & $8(5.8)$ & $3(6.0)$ & $1(7.7)$ & 0 & $12(5.8)$ \\
\hline & H. diminuta & 0 & 0 & $1(0.71)$ & 0 & $3(23.1)$ & $1(50.0)$ & $5(2.4)$ \\
\hline & H. nana & 0 & 0 & $2(1.4)$ & $2(4.0)$ & 0 & $1(50.0)$ & $5(2.4)$ \\
\hline & Isospora sp. & 0 & 0 & $10(7.2)$ & $4(8.0)$ & $1(7.7)$ & 0 & $15(7.2)$ \\
\hline & M. muris & 0 & $1(50.0)$ & $5(3.6)$ & $4(8.0)$ & $1(7.7)$ & 0 & $11(5.3)$ \\
\hline & M. moniliformis & 0 & 0 & 0 & $1(2.0)$ & 0 & 0 & $1(0.48)$ \\
\hline & N. brasiliensis & 0 & 0 & $5(3.6)$ & $4(8.0)$ & $5(38.5)$ & 0 & $14(6.8)$ \\
\hline & Strongyloides sp. & $1(100.0)$ & 0 & $8(5.8)$ & $5(10.0)$ & $5(38.5)$ & 0 & $19(9.2)$ \\
\hline & Trichosomoides sp. & 0 & 0 & 0 & 0 & $1(7.7)$ & $1(50.0)$ & $2(0.96)$ \\
\hline & Trichuris sp. & 0 & $1(50.0)$ & $9(6.5)$ & 0 & 0 & 0 & $10(4.8)$ \\
\hline \multirow[t]{3}{*}{ Blood parasites } & Babesia sp. & 0 & $2(100.0)$ & $1(0.75)^{a}$ & $1(2.0)^{b}$ & 0 & 0 & $4(2.1)^{c}$ \\
\hline & Plasmodium sp. & 0 & $2(100.0)$ & $63(47.4)^{\mathrm{a}}$ & $21(42.9)^{b}$ & $7(53.8)$ & $1(50.0)$ & $94(49.0)^{c}$ \\
\hline & Trypanosoma lewisi & 0 & 0 & $7(5.3)^{\mathrm{a}}$ & $2(4.1)^{b}$ & 0 & 0 & $9(4.7)^{c}$ \\
\hline \multirow[t]{2}{*}{ Brain parasites } & Angiostrongylus sp. & 0 & 0 & $3(2.2)$ & 0 & 0 & 0 & $3(1.4)$ \\
\hline & T. gondii & 0 & 0 & $1(0.71)$ & $1(2.0)$ & 0 & 0 & $2(0.96)$ \\
\hline
\end{tabular}

aPercentage positive calculated with $M$. musculus sample size $(n=133)$.

${ }^{b}$ Percentage positive calculated with $R$. rattus sample size $(n=49)$.

${ }^{c}$ Percentage positive calculated with a total rodent sample size $(n=192)$. 
Supplementary Table 5. Prevalence of parasites of small mammals trapped in Uromi

\begin{tabular}{|c|c|c|c|c|c|c|c|c|}
\hline \multirow{2}{*}{\multicolumn{2}{|c|}{ Parasite/small mammal }} & \multicolumn{7}{|c|}{ No. of mammals (\%) } \\
\hline & & \multirow{2}{*}{$\begin{array}{c}\begin{array}{c}\text { Apodemus sp. } \\
(n=1)\end{array} \\
0\end{array}$} & \multirow{2}{*}{$\begin{array}{c}\text { M. natalensis } \\
(n=2)\end{array}$} & \multirow{2}{*}{$\begin{array}{c}\text { M. musculus } \\
(n=71) \\
1(1.4)\end{array}$} & \multirow{2}{*}{$\begin{array}{c}\text { R. rattus } \\
(n=15)\end{array}$} & \multirow{2}{*}{$\begin{array}{l}\text { R. norvegicus } \\
(n=2)\end{array}$} & \multirow{2}{*}{ 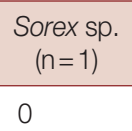 } & \multirow{2}{*}{$\begin{array}{c}\begin{array}{c}\text { Total } \\
(n=92)\end{array} \\
2(2.2)\end{array}$} \\
\hline Intestinal parasites & Aspicularis sp. & & & & & & & \\
\hline & Eimeria sp. & $1(100.0)$ & 0 & $12(16.9)$ & $7(46.7)$ & $1(50.0)$ & 0 & $20(21.7)$ \\
\hline & H. spumosa & 0 & 0 & $4(5.6)$ & 0 & 0 & 0 & $4(4.3)$ \\
\hline & H. nana & 0 & 0 & 0 & 0 & 0 & $1(100.0)$ & $1(1.1)$ \\
\hline & Isospora sp. & 0 & 0 & $10(14.1)$ & 0 & $2(100.0)$ & 0 & $3(3.3)$ \\
\hline & M. muris & 0 & 0 & $2(2.8)$ & $2(13.3)$ & 0 & 0 & $4(4.3)$ \\
\hline & N. brasiliensis & 0 & 0 & $1(1.4)$ & $2(13.3)$ & 0 & 0 & $3(3.3)$ \\
\hline & Strogyloides sp. & 0 & 0 & $5(7.0)$ & $1(6.7)$ & $1(50.0)$ & 0 & $7(7.7)$ \\
\hline & Trichuris sp. & 0 & 0 & 0 & $1(6.7)$ & 0 & 0 & $1(1.1)$ \\
\hline \multirow[t]{2}{*}{ Blood parasites } & Babesia sp. & 0 & 0 & $2(3.3)^{a}$ & 0 & 0 & 0 & $2(2.7)^{d}$ \\
\hline & Plasmodium sp. & 0 & $1(50.0)$ & $37(62.7)^{\mathrm{a}}$ & $7(50.0)^{b}$ & $1(100.0)^{c}$ & 0 & $46(61.3)^{d}$ \\
\hline Brain parasites & - & - & - & - & - & - & - & - \\
\hline
\end{tabular}

aPercentage positive calculated with M. musculus sample size $(n=59)$.

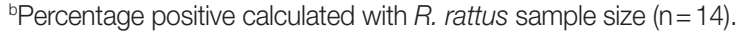

${ }^{c}$ Percentage positive calculated with only $1 R$. norvegicus.

dPercentage positive calculated with a total of 75 rodents. 